\title{
Sculpting an Information Literate School Community: Looking for Touchstones
}

\author{
James Henri \\ Centre for Information Technology in School and Teacher Education \\ Faculty of Education \\ University of Hong Kong \\ Pokfulam Road \\ Hong Kong \\ james@cite.hku.hk \\ Suzette Boyd \\ Head, Scotch College Library and Information Centre \\ Morrison Street \\ Hawthorn, Victoria 3122 \\ Australia \\ Suzette.Boyd@scotch.Vic.edu.au \\ Gayner Eyre \\ Lecturer, School of Information Studies \\ Charles Sturt University \\ Locked Bag 675 \\ Wagga Wagga, NSW, 2678 \\ Australia. \\ geyre@csu.edu.au
}

\begin{abstract}
The authors review, and provide findings from, a collaborative action research project in a large private school. The purpose of the research was to implement actions to facilitate a holistic approach to information literacy, and to embed information literacy within teaching units in the school. A second aim was to benchmark best practice. The research took the form of a situation analysis and individual case study 'units'. The experience has created awareness, amongst teaching staff, of techniques and resources to improve the information literacy process amongst students, and of the potential role of the library in collaborative practices.
\end{abstract}

\section{Introduction}

The concept of the information literate school community (ILSC) was coined in 1995 (Henri, 1995). In 1999 the first major work on the topic was published (Henri and Bonanno 1999). Since that time a growing literature on the topic has emerged (133,000 hits 30 May 2002: Google), however, little of this literature is research based. There seems to have been few serious attempts to demonstrate that a journey towards an information literate school community makes a difference to learning outcomes and to motivation for learning. 
The emerging interest in Knowledge Management (KM) and Knowledge Building (KB) has perhaps overshadowed the importance of information literacy and the building of school communities that focus on the attainment of information literacy. The writers would argue that information literacy (IL) is a fundamental (conceptual and pragmatic) building block of all knowledge. KM is, in practice, about information (explicit knowledge) and ideas (tacit knowledge). Much of the literature is about managing explicit knowledge and finding ways to share and codify tacit knowledge (Hanson, 2001; Eustace \& Hay, 2001; Todd, 2001). $\mathrm{KB}$ is about the pursuit of information literacy but in practice $\mathrm{KB}$ is often classroom based (rather than school based) and dependent upon individual teachers. The ILSC as defined by Henri (2000b)

A school community that places a high priority (policy, benchmarking, funding, and evaluation) on the pursuit of teacher and student mastery of the processes of becoming informed can be regarded as an information literate school community focused attention and responsibility, beyond individual teachers, beyond individual classrooms, beyond information services, to the policy level.

Seen in this way the ILSC concept is a cousin to that of the learning community (Senge, 1990). The learning community idea can be seen in terms of the two components:

Learning: connotes ongoing action and perpetual curiosity, and engagement. The learning paradigm rather than the instruction paradigm gives primacy to the learner and learning outcomes over the teacher and instruction. This paradigm also 'extends learning beyond the classroom and builds on students' interests, critical thinking, and problem solving skills' (Mitstifer \& Miller, 1999:16).

Community: implies a group linked by common interests.

The essential distinction between the concepts is the primacy given to informing processes within the ILSC.

This paper outlines the processes involved in an action research project that attempted to achieve a whole school approach to information literacy, and therefore to develop an information literate school community.

\section{Background to Scotch College}

Scotch College Melbourne, is a school 'with a long and distinguished history in Australia.' Established in 1851, it is a Presbyterian school for boys from prep- year 12. The Senior School consists of 1400 students and the Junior School of about 400 students. The students come from some of Melbourne's leading and most influential families. The focus of this paper is on the students in the senior school years $(7-12)$.

There are 125 teachers, most of whom are male. Many of the academic staff have taught at Scotch for over 15 years and some of these teachers exhibit many of the characteristics identified by Bruce (1994) as being counter-productive to information literacy development:

- heavy dependence upon "teaching/lecturing" for the transmission of information

- providing all resources required by students rather than encouraging students to explore knowledge bases independently

- heavy reliance upon reading lists / department collections / boxes of books / class sets

- lack of an understanding of the skills of information literacy 
- setting "find out about" assignments

- teacher generated questions, rather than student generated enquiry

All staff and students have access to the College intranet, a Citrix Server and the Internet. The students do not yet have school e-mail accounts and only year 11 and 12 students have laptops. All teaching staff are issued with a laptop and extensive use is made of the Intranet Workbench, the library home page and e-mail by staff.

Currently the Library and Information Centre is staffed by: the Head of Library, 2 other teacher-librarians, 1 teacher, 1 acquisitions librarian, 1 reference librarian, 1 webrarian, 1 media and technology technician and 1 library technician.

Part of the library's mission reads:

The library is central to implementing, enriching and supporting the teaching and learning program of the college. We are proactive in developing information literate students and supporting an information literate community

\section{The challenge}

Researchers Henri (Centre for IT in School and Teacher education), University of Hong Kong) and Eyre (Centre for Studies in Teacher Librarianship, Charles Sturt University), joined with Suzette Boyd (Director of Library Services, Scotch College) to develop a collaborative approach, including action research and participatory evaluation, to identify the quality of information literacy at Scotch College. In addition they saw the opportunity to provide touchstones demonstrating that a focus on information as the key ingredient to learning does make a difference to motivation and achievement among students and staff. Essentially the aim of the project was to:

$>$ Facilitate a whole school approach to information literacy.

$>$ Test and develop information literacy standards.

$>$ Assist in the benchmarking of best practice.

$>$ Determine a set of appropriate information literacy scaffolds.

$>$ Facilitate changing practices to underpin autonomous learning.

$>$ Provide information that empowered policy development.

The challenge can be seen from two distinct perspectives.

Outsider perspective: The outsiders saw the project as an exciting opportunity to spend time within a school and to obtain exposure to real-life issues. Such opportunities are rare and often difficult to achieve. The outsiders were given an opportunity to test their 'ivory tower' ideas within a practical setting. They also anticipated being able to use the opportunity to refine their conceptual models as the practice, and reflection on that practice, informed the theory. As academics the outsiders were interested in the opportunity to disseminate the outcomes of the project as a way to further building the knowledge base.

The research component of the project provided a strong base for effective practice. A strong research base underpinning practice could substantially enhance the credibility and profile of the school, those involved in the project, and provide role clarification for the information professionals within the school. At the very least the research project would encourage greater reflection about practice.

Insider perspective: In order to completely understand the insider perspective it is necessary to examine some of the stages leading up to the project. 


\section{Pre 1996 - information literacy NOT on agenda}

- Head of Library as manager, not working as a teacher-librarian.

- No evidence of information literacy teaching

1996 - 2000 - 'Research skills' on agenda

- Appointment of teacher-librarian to teach 'research skills'

- Reality was finding 'stuff' for teachers and conducting 'locating' classes

- No collaboration with teachers

- Being 'on demand' when classes came to library

2000 - 'Information literate school community' NOW on the library agenda

- Appointment of new Head of Library with a focus on information literacy

- Report and recommendations to senior executive included the need to work towards an information literate school community.

\section{Mid 2000}

- Recognition for the ROLE of teacher librarian by the College

- Appointment of second teacher librarian

- Teacher librarians working with classes - whenever a class coming into the library has already requested a pathfinder, they are encouraged to seek the assistance of a teacher-librarian to explain how the pathfinder works. These offers are rarely refused and from that first lesson on, library staff are usually asked to work with the boys on subsequent visits to the library. This allows the opportunity to work one-on-one with the students, guiding them through the resources on the home page, and also gives the teacher the opportunity to become involved in learning. It is a strategy that seems to be working, and requests from teachers are increasing.

\section{1 - Making information literacy happen in the school}

The need for an information literacy project (ILP)

In order to come somewhere near to meeting the benchmarks identified by Henri (1999) as hallmarks of an 'information literate school community' there was a need to change some of the teaching practices that were embedded at Scotch. It was necessary to encourage teachers to:

- Assist students become autonomous learners

- Equip students with lifelong learning skills for information problem-solving

- Embed information literacy in collaborative practical activity in order that students know what they are learning, why they are learning and how they are learning it

- Take students from being information consumers to information producers

- Take students beyond information retrieval towards understanding, wisdom and insight

- Equip students with the skill to critically evaluate information

Information literate students are competent, independent learners. They know their information needs and actively engage in the world of ideas. They display confidence in their ability to solve problems and know what is relevant information. They operate comfortably in situations where there are multiple answers, as well as those with no answers. They hold high standards for their work and create quality products. Information literate students are flexible, can 
adapt to change and are able to function independently and in groups (Pennell 1999)

With this in mind, at the beginning of 2001, when the Director of Educational Research and Development invited Heads of Department to apply for research money for their department, the library applied to undertake an Information Literacy Research Project in conjunction with Charles Sturt University. The proposal was successful.

Six classroom teachers, one educational support teacher and three teacher librarians, worked together to embed information literacy skills into units of work. Classes involved were from year 8 to year 11 and subjects included Economics, English and Science.

It was anticipated that this project, while building on existing strong programs, would be effective in demonstrating that teachers and teacher librarians operating as teams in a planned and collaborative way will improve the chances of improved learning outcomes and information literacy skills for students.

\section{What Outcomes were sought?}

The staff wanted to:

- analyse the way teachers deliver research assignments to students

- raise questions about the way students research

- develop strategies to improve information literacy skills

- develop and measure interventions

- gather and analyse data

- pose new questions

- empower teachers to be information literacy mentors for their colleagues

\section{Literature Review}

Henri $(1995,1999)$ suggested a series of benchmarks for determining how well the school was progressing towards an ILSC. McKenzie (1998) suggested that an ILSC has a set of traits that can be measured. The traits are: Invention, fluency, support, navigation, searching, selection, questioning, planning, interpretation, deep thinking, and commitment.

Hay, Henri and Oberg (2002) reported on an international research project that attempted to examine the principal-school librarian relationship, and principal influence in forging an ILSC. The participating countries were: Australia, Canada, Finland, France, Japan, Scotland, and South Korea.

Farmer (2001) reported on an action research project at Redwood High School. The study was driven by a number of concerns. These included: problems students experienced in accessing and evaluating information; student research questions were sometimes vague and underdeveloped; group work in the library was sometimes inefficient; teachers noticed a rise in student plagiarism; students voiced their frustration with assignments; and teachers did not own the information skills model adopted by the school. through:

The aim of the project was to improve student information literacy competence

- Developing a repertoire of research strategies 
- critically evaluating information

- Synthesizing and sharing information in creative, meaningful ways

- Incorporating technology into the literacy process.

Two major research questions were posed:

- What information skills do students need to demonstrate?

- What interventions will improve student skills?

At the conclusion of the first phase of the project, Farmer reported that:

- Assignments included clearer and more explicit language about information literacy skills.

- Assignments within in the same course were more uniform.

- Students and teachers made great use of the research guides.

- Classes of students asked more high-level questions when doing research.

- Web site evaluation was taught explicitly in the freshman computer course, and practiced in that grade's science and social studies assignments.

- More attention was made to research process along with research product.

- More students completed research assignments, and work was more solid.

- Reading skills improved.

- Resources were cited more often and more accurately.

- Less plagiarism was evident.

- Information professionals were more involved in the research process, including the assessment of research products.

\section{Methodology}

The project at Scotch College incorporated a research element and an evaluative element. It involved both qualitative and quantitative elements and was conducted within a collaborative and participatory framework. Since the agenda from the Scotch perspective was to improve practice through reflection, the action research model was an appropriate one.

Farmer (2001) claimed that action research is associated most closely to the Teachers College of Columbia University in the 1940s (although in more recent times it has become a widely used, though still controversial, research tool made popular by Kemmis and McTaggart (1990) of Deakin University). Farmer stated:

The main idea [of action research] was to give teachers an empirical way to improve practice. Action research may also be considered as a cycle of inquiry, whereby: 1) the present situation is analyzed, 2) questions are raised, 3) factors are identified, 4) solutions are proposed, 5) interventions are developed and measured, 6) data are gathered and analyzed, and 7) new questions are posed. Action research provides a reasonable way to improve student achievement as well as educational practice. Particularly when variables are hard to control, action research at least provides a systematic approach and encourages reflective decision-making. (Farmer 2001: 1)

Hopkins (1985) provided a similar view.

Action Research is a form of self-reflective enquiry undertaken by participants in social (including educational) situations in order to improve the rationality and justice of (a) their own social or educational practices, (b) their understanding of these practices, and (c) the situations in which the practices are carried out. It is 
most rationally empowering when undertaken by participants collaboratively ...sometimes in cooperation with outsiders.

The action research framework is most appropriate for participants who recognize the existence of shortcomings in their educational activities and who would like to adopt some initial stance in regard to the problem, formulate a plan, carry out an intervention, evaluate the outcomes and develop further strategies in an iterative fashion (Hopkins, 1993).

Action research is cyclical in nature and is intended to foster deeper understanding of a given situation, starting with conceptualising and particularising the problem and moving through several interventions and evaluations.

Fig. 1 The Action Research Spiral

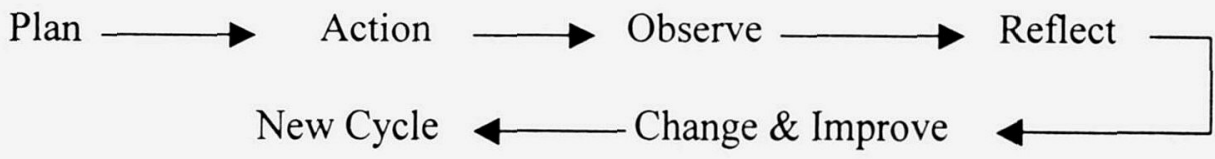

The researchers also employed a form of participatory evaluation (Cousins 2002) to enable benchmarking. This process entailed: semi structured interviews with a sample of teachers, information professionals and students; questionnaires administered to a sample of teachers and students, and document analysis.

\section{Action Research at Scotch College}

Action research has two foci: action in practice and knowledge creation through rigorous research (Oosthuizen 2000: 141).

Action research is often intended to bring about a change of practice, while creating knowledge at the same time. These combined characteristics make it useful for exploratory research to bring about improvement in practice, or to propose new solutions to practical problems (Oosthuizen 2000:143).

The Scotch College project conformed to action research in the following ways: critical reflection was part of the methodology and each cycle was followed by evaluation: the researchers participated in the activity. In addition, in action research a change in practice usually occurs, often with (as in this study) an improvement in practice.

Dick (1997) provides a useful framework for rigorous action research, demonstrated by the following model:

Fig. 2 Components of the action research process

\begin{tabular}{|c|c|c|}
\hline $\begin{array}{c}\text { Action } \\
\text { Strategies } \\
\text { (A) }\end{array}$ & $\begin{array}{c}\text { Research } \\
\text { Strategies }\end{array}$ & $\begin{array}{c}\text { Data } \\
\text { Strategies } \\
\text { (B) }\end{array}$ \\
\hline (C) \\
Action & Research & Data \\
Tactics & Tactics & Tactics \\
(D) & (E) & (F) \\
\hline
\end{tabular}


As a brief explanation the Action and research strategies (A, B, C) involve the planning elements, largely undertaken by the researchers, and the tactics comprise the day-to day processes such as communication and provision of resources, which was largely performed by the library staff. Both the action and research phases generate knowledge and information, which in this model are called data.

The Scotch College project comprised 2 major elements of research:

- A Situation Analysis to provide the context for the action research modules.

- Individual Action Research case studies, referred to hereafter as units (which also included action)

And, in order to facilitate the process, a number of elements of Action, which will be explored at a later stage, were undertaken.

The third dimension was evaluation, or multi-evaluations of the process.

The activities under each of these umbrellas included the phases A-F of Dick's model, with a proposed data model as one of the outcomes of the study. Within both of the elements of process, a variety of methods were used, and each element contained a number of cycles of activity. Action Research cycle(s) typically contain multiple elements (Oosthhuizen 2000: 144), and therefore, as with all research methodologies, contain a package of activities and varying methods of enquiry. Usually action research is applied to single situations but in this particular project, mini satellite action research projects were undertaken within the overall aim of facilitating a whole school approach to information literacy.

One of the features of Action Research, and true in the Scotch College project, is that it can rarely be systematically planned in advance, as it is a process in which data and process are generated in an explorative manner (Oosthuizen 2000:147). Through action and reflection, early insights are used to generate further actions. In line with this, it was found that in the Scotch College study the activities overlapped, for example the situation analysis took place simultaneously with the actions required to facilitate the project, though for ease of understanding the various activities are presented here in linear fashion.

The collection of data in every cycle is important in a project of this kind. We attempted to use a variety of methods and a variety of informants in order to include rigour into the process and to verify the data we obtained.

Methods for both phases of the study included, in general terms, multiple case studies within which, focus groups, individual interviews and observation were the main data collection techniques. These were juxtaposed with the actions needed to facilitate the process or change factor.

Having established the broad question, it was necessary for the researchers to explore the information literacy environment to provide a context for the project. The process included inductive reasoning in that the researchers immersed themselves in the culture of the school in order to collect data, which could then be interpreted to develop concepts and insights from the emerging data patterns. This phase has been called here the situation analysis. 
The main method used to collect the data in this phase was convergent interviewing of selected key senior staff. The chief value of this technique is in establishing important facts when the researchers are not sure of the information to be collected. Usually the process begins with a single, overarching question, from which the interviewee is encouraged to talk for as long as possible. Usually this results in important issues being highlighted. Follow up questions or probes are used to explore areas which are unclear or where further detail is required. Interviews were largely individual, although Focus group interviews with selected students, teachers and Teacher Librarians involved in action research were also carried out. In parallel, key documents in the school were collated and analysed in order to give a brad picture.

In order to gain an holistic view, interviews were held with:

- key support staff in school such as the learning support staff

- members of the school executive, for example two key people in terms of the study, the head of information technology and the head of research

- key teachers, including, but not exclusively, those with whom the case studies were to be undertaken

- teacher librarians and other library staff

- students

\section{Findings of the Situation Analysis Phase}

A number of contextual issues, which had the potential to impact on the project, arose. The first category of issues related to the culture of the school and how that impacted on innovation and change. This included several major factors:

- communication channels and territorial issues

- the approach to teaching and examinations

- the extent of collaboration and teamwork within the school

- perceptions of the library and its role by teachers, pupils and senior management

- the level of relationships between key people

- the level and quality of IT support

- students' ability and knowledge

- the perceptions of teacher librarians and other staff

The situation analysis also provided an audit of the current information literacy environment within the school. The issues here related to:

- the existing framework for information literacy practices:

- the level and consistency of student skills

- the level of information amongst teachers about skills related to Information Literacy

- the processes in place to facilitate systematic skill development

- the existing role and potential of the library

- the expectations and goals of library staff

- ensuring availability of adequate resources

Finally, the situation analysis provide the researchers with information relating to the level of the Information Literacy skills of teachers, pupils and library staff, namely:

- a general understanding of the process and the steps within it

- ability in forming research questions

- skills in defining and refining area of research 
- search skills and preferences

- synthesis and analysis skills

- the level of and issues related to plagiarism

- presentation and communication skills

\section{Action Research Units \\ In the Beginning}

Working towards the aims and objectives of the project as specified by the Director of the Library at Scotch College, the researchers initiated a range of actions at the commencement of the project. The main areas to be resolved were:

- selection of participating teachers

- selection of appropriate topics and joint refinement of topics

- establishment of the elements of the research process required within each topic

- professional development activities

- facilitation of communication between teacher librarians and teachers to establish resources

The actions to fulfil the above requirements were multi-faceted.

\section{Mentoring of teaching and library staff involved in the units}

One of the first priorities was for the researchers and library Director to outline the nature and scope of the project to the teacher librarians and library staff. This took place in initial meetings, but because of the nature of the cyclical, reflective element of action research, liaison was of necessity, ongoing. The teacher librarians and the library Director then had the further task of identifying potential Units and teachers, with whom they would work alongside during the mini projects.

\section{Adoption of a set of rubrics and an information process model}

Kuhlthau's Information Process model (1993: 45-51) was used as a basis for the project. This was simplified and adapted locally by the teacher librarians, for inclusion in an information literacy pack.

\section{Development of a pack of background reading and template}

An information pack was developed to include, in addition to the process model, indicative readings provided by the researchers, useful school documents, such as essay planning templates devised by the Education Support Teachers, templates for WebQuests and a variety of other similar items. The intention of the pack was, in the first place, to inform and act as a resource for teacher participants and library staff involved in the initial s. It was envisaged, however, that the pack would be a dynamic entity and that as projects evolved, participants would add to the pool of useful documentation and this could then inform future projects. For this reason, the intention was to mount it on the Library Website.

\section{Provision of PD to volunteer teachers}

Once some of the initial actions and principles had been established, and volunteer teachers identified, information and training sessions took place, in order to outline some of the detailed concepts. The researchers provided training and development initially, but as confidence grew, these duties were taken over by the teacher librarians. The library also ran training sessions on specific aspects relating to the Information Literacy process, for example, a seminar on Avoiding Plagiarism. 


\section{Commencement of a series of action research Units aimed to test changing pedagogical practice}

After completion of the preparatory work, a stage in the project was reached where the individual projects could be developed and each participating teacher was partnered with a designated teacher-librarian. The planning stage for each project involved a series of meetings, which included the researchers, the teacher and teacher librarian. The purposes of the meetings were to define and refine the topic area, the desired outcomes and those elements of the information literacy process, which were seen to be important.

The individual units

A number of initial projects were devised across subject departments and on diverse topics. Some of these projects were to blossom, whilst others disappeared to be replaced by others. This particular study may differ from other research projects too, in that it was a project, designed not to be self-contained, but to provide a basis for ongoing activity, after the project per se had ended. It was envisaged that the initial projects would be built upon, and cascaded to other subject areas. The projects outlined below, give some indication of the range and scope of the projects

\section{Topics}

The table below (Figure 3) outlines the nature and titles of the projects, and also indicates the information literacy steps, highlighted within each project. The names of personnel involved in the project have been omitted here in the interests of confidentiality.

Although each project was different in nature, there were some common aspects.

- Each of the units involved high level communication and collaboration

- Each of the units was jointly planned by the researchers, teacher librarians and other staff involved

- The execution of each unit included integration of the relevant information literacy issues, and continuous, focused input from the library

- The teacher librarians were involved in classroom activities related to the unit

- Each of the units included a reflective element for both pupils and teachers

- Each of the units was evaluated for effectiveness by the teacher and by the researchers

Evaluation

Evaluation is an important element of any action research project. It is also multilayered. In the Scotch College project, evaluations were undertaken at the beginning and end of each unit, and at the end of the overall project. The researchers sought to elicit the views of all participants, students, teachers and library staff. In addition, teachers evaluated the learning outcomes prior to and at the end of each unit. Evaluation techniques included the use of focus groups, observation and document analysis. 


\begin{tabular}{|c|c|c|c|c|}
\hline 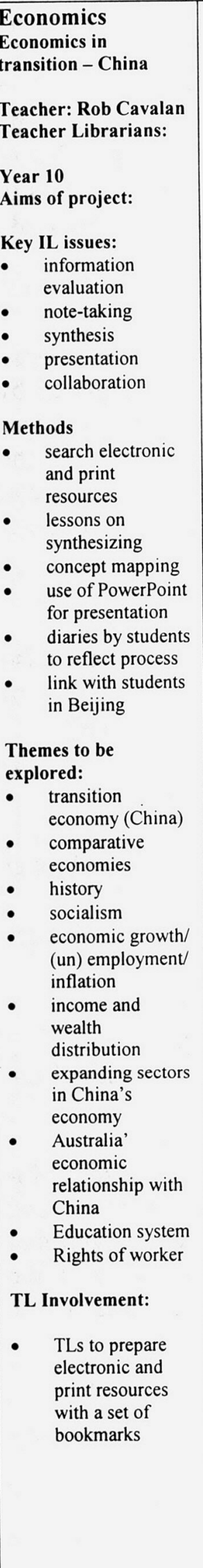 & $\begin{array}{l}\text { English } \\
\text { Favourite authors } \\
\text { Teacher: } \\
\text { Teacher } \\
\text { Librarians: } \\
\text { Year } 10 \\
\text { Aims of project: } \\
\text { Key IL issues: } \\
\text { - focus } \\
\text { - formulation } \\
\text { - } \quad \text { anale-taking } \\
\text { - synthesis } \\
\text { Methods } \\
\text { brainstorming } \\
\text { lessons on } \\
\text { synthesizing } \\
\text { TL Involvement: } \\
\text { - lessons on } \\
\text { synthesizing }\end{array}$ & 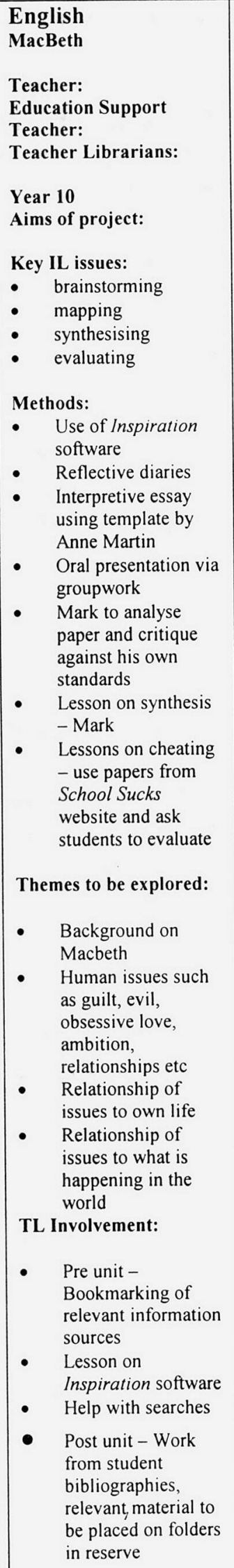 & $\begin{array}{l}\text { Science } \\
\text { Food and digestion } \\
\text { Teacher: } \\
\text { Teacher Librarians: } \\
\text { Year } 10 \\
\text { Aims of the project: } \\
\text { Key IL issues: } \\
\text { - Evaluation } \\
\text { - note-taking } \\
\text { presentation } \\
\text { communication } \\
\text { Methods: } \\
\text { - Customised } \\
\text { webquest } \\
\text { group work } \\
\text { - template on web } \\
\text { evaluation } \\
\text { Diaries } \\
\text { - Pre and post } \\
\text { testing } \\
\text { TL Involvement: } \\
\text { Pre unit - } \\
\text { Bookmarking of } \\
\text { relevant } \\
\text { information } \\
\text { sources } \\
\text { Availability of } \\
\text { and lesson on } \\
\text { Inspiration } \\
\text { software } \\
\text { Help with } \\
\text { searches }\end{array}$ & $\begin{array}{l}\text { English } \\
\text { Newspaper issues } \\
\text { Teacher: } \\
\text { Teacher Librarians: } \\
\text { Year } 10 \\
\text { Aims of project: } \\
\text { Key IL issues } \\
\text { Analysis } \\
\text { Locating articles } \\
\text { Defining topic } \\
\text { Methods: } \\
\text { - Groupwork } \\
\text { - Use of Scaffold/ } \\
\text { matrix to aid in } \\
\text { analysis } \\
\text { - Oral presentation } \\
\text { - Diary on group } \\
\text { work } \\
\text { Peer and self } \\
\text { assessment } \\
\text { Themes to be } \\
\text { explored: }\end{array}$ \\
\hline
\end{tabular}

Fig.3 Table of initial units demonstrating desires outcomes and process 


\section{The Outcomes of the Project}

Six months later, information literacy is clearly on the agenda at Scotch College. It is being supported through the compilation, distribution and promulgation of an Information Literacy Handbook; through the appointment of an additional teacher to the staff of the library; through teacher librarians working alongside teachers and students in year 7 teams to develop and teach units of work which incorporate information literacy skills; through further development of the library home page as a pivotal element in supporting the curriculum; and through support from the Principal and other decision-makers and acknowledgment that there is work to be done in sculpting the information literate school community and that the library's role is central to that process.

\section{Information Literacy Handbook}

An outcome of the ILP was a recommendation that the teacher librarians compile a handbook for use by teachers. This resource was to include:

- the information literacy process

- an information literacy skills continuum, year $7-12$

- a skills checklist from years $7-12$

- the role of the teacher librarian

- templates to support the six steps in the information process

- a set of rubrics

This handbook was completed by the end of 2001 and distributed to all year 7 teachers ( 25 in total) at the beginning of 2002. The teacher librarian and teacher (library) attached to the ten year 7 teams are able to map the skills developments of each year 7 class and suggest skills foci for forthcoming project work. Currently all teaching staff at Scotch has a copy of the handbook. It is also available on the College intranet, so teachers at any year level can download templates for use with their classes.

\section{Staffing}

An additional teacher was appointed to the library staff at the start of 2002. This new appointment reflected the commitment the College was making to towards an information literate school community. It was decided that this teacher would be allocated only a minimum of duties in the library to enable her to work directly and 'on demand' with teachers.

Alongside the teacher librarians she:

- works with the teacher to plan, design, deliver and evaluate instruction

- serves as teacher and consultant

- provides leadership, expertise and advocacy in the use of technology and resources

- models the use of the 'information literacy handbook'

- encourages students to accept responsibility for their own learning

\section{Teams}

At the commencement of 2002, each teacher in the library was allocated to one of the ten year 7 teams as a partner in learning. These members of the library staff attend all team meetings, support collaborative and cross-curricula projects and team-teach with class teachers. In addition, their role encompasses all of those listed above. 


\section{Library Home Page}

Scotch College has become an on-line information provider through the library home page. It is a valuable resource and is the place where staff and students are encouraged to begin, when undertaking any form of research. The home page, in conjunction with topic pathfinders will guide all users to the information available from the College library. It is a "one-stop-shop" for information, supporting information literacy development through:

- on-line electronic data bases

- web-based library catalogue

- Internet links for all subjects

- reference centre

- pathfinder to current information

- professional development program for staff

Teachers were primarily concerned about finding appropriate sites for use with their classes. Even though there was a selection of curriculum links for all subjects available on the Scotch home page, members of staff were often unaware of the existence of these links. Not only were they unaware of the curriculum links, but also were often ignorant of the fact that we had a web-based library catalogue, and on-line databases also accessible from the library home page.

\section{Professional development (PD) of teachers}

All teachers are involved in a wide range of co-curricular activities, including sport, drama, music, services, debating, cadets and many more. This results in all teachers having at least two nights of after-school commitments, along with lunchtime rehearsals, meetings and practices. This makes it difficult to organise in-house PD opportunities. However, there is a time put aside on Friday afternoons for faculty meetings from 3.00-4.00. This is potentially the only time during the week for any on-going systematic professional development to occur.

Teacher librarians work with teachers to:

- inform them about the content of the library home page as a resource for teaching and learning

- restructure the teaching/learning process for student-centred and independent learning

- explore creative ways to incorporate the teaching of the information skills process into the curriculum

- develop strategies for assessing information literacy skills

- develop a continuum of increasingly complex information literacy skills across years $7-12$

- encourage teachers to set research tasks that eliminate plagiarism

- inform teachers about evaluating information on the internet

- use information technology in teaching and learning

- When talking to teachers about their classes or running PD sessions, they are asked if they are able to provide any Internet addresses for inclusion under their curriculum area on the library home page. This encourages their involvement in its content. If they have had been involved in selection of sites, they are more likely to refer students to the home page.

\section{Role of the principal and senior management}

- Principal provides the vision and the structures and a 'top-down mandate' for the development of an information literate community 
- Fosters a culture of collaboration

- Provides the budget and time for professional development, which is essential for teachers to effect a change in their teaching strategies and become information literate themselves. (Pennell 1999)

- Provides a solid technical infrastructure to support learning technologies

- Ensures the library is adequately staffed and funded

What was learned from involvement in the Information Literacy Project?

- Reflective practice is essential

- The profile and credibility of the teacher librarian is enhanced through partnership with teachers

\section{Suggestions for Further Research}

A project such as this generates a great deal of information. Incidental observation of the students using electronic facilities has already led to collaborative research with the University of Wales. This research is in the form of a bilateral study, to take place in the UK and Australia, of the use of information databases by high school students linking in with research looking at tertiary students information practice, previously undertaken by the University of Wales.

One of the proposed outcomes of the Scotch College project was the development of a set of information literacy scaffolds. Templates connected with this are still under development, but once completed it is suggested that these be tested in other schools of differing backgrounds.

It would also be interesting to replicate parts of the study, such as the teaching units, in other schools and to measure the outcomes. Issues such as the impact of school infrastructure may then be assessed to determine the influence of the information literacy environment on achieving a whole school literacy approach.

Lastly, information literacy is emerging as an issue in higher education institutions, and also in the workplace. Many of the questions and models resulting from the Scotch College project could be tested in these situations.

\section{Bibliography}

American Association School Librarians (AASL) and Association for Educational Communications and Technology (AECT). (1998). Information Power: Building Partnerships for Learning. Chicago: American Library Association, 8-22.

A collection of web resources aimed at assisting teachers in learning more about the information literate school community. (Online) http://ww.lane educ.ubc.ca/libe/libe $477 \mathrm{a} . \mathrm{htm}$

Credaro, A. (2001). Schools as information literate learning communities. (Online) http://www.geocities.com/Athens/Styx/7534/UNIVERSITY/TLship/infolit_comm.html

Cousins, B. (2002) Research on participatory evaluation. Greenwich, CT: Information Age Publishing. 
Bush, G. (1999). Creating an information literate school: Here and now. NASSP Bulletin 83(605): 62-67.

Dick, B. (1997). Action research and evaluation. (Online) http://www.scu.edu.au/schools/sawd/areol/-sessionl0.html

Farmer, L. (2001). Information literacy: A whole school reform approach. Paper presented at the 67th IFLA Council and General Conference, Boston, August 16-25. (Online) http://www.ifla.org/IV/ifla67/papers/019-106e.pdf

Hanson, K. (2001). Surfing the subjective memory: Granularity or innovation? In Hay, L. Hanson, K. \& Henri, J. New millennium, new horizons: information services in schools. Wagga Wagga, NSW: CSTL: 19-25.

Hay, L. \& Eustace, K. (2001). Groupware as a knowledge management tool. In Hay, L. Hanson, K. \& Henri, J. New millennium, new horizons: information services in schools. Wagga Wagga, NSW: CSTL: 26-39.

Hay, L. \& Henri, J. (1995). Leadership for collaboration: Making the vision work. Paper presented at the 61st IFLA General Conference Proceedings August $20-25,1995$. (Online) http://www.ifla.org/IV/ifla61/61-hayl.htm

Hay, L., Henri, J. and Oberg, D. (2002). An international study on principal influence and information services in schools: Synergy in themes and methods. School Libraries worldwide. (In press)

Henri, J. (1995). The information literate school community: Exploring a fuzzy concept. Scan, 14 (3) $25-28$.

Henri, J. (1999). The information literate school community: Not just a pretty face. Henri, J. \& Bonanno, K. (1999). The information literate school community: Best practice. Wagga Wagga: CIS. 1-10.

Henri, J. (2000a). An Information Literate School Community: Searching for benchmarks Keynote presented at the School Library Association of Victoria (SLAV) Conference, Melbourne, 22 March. (Online) http://athene.mit.csu.edu.au/ khanson/Slav2000_files/frame.htm

Henri, J. (2000b). The information literate school community and authentic assessment. Presentation to Tasmanian Education Department. Hobart. 30 October.

Henri, J. (2000c). The information literate school community and the role of the principal. Paper presented at C2000 WASLA conference. Perth. 3 June.

Henri, J. (2000d). The information literate school: Definitely more than a pretty face. Keynote address to ASLA (NSW) annual general meeting and conference, Sydney, 19 February. 
Henri. J. (2000e). Teachers seeking, using and making information: What do we know? In Enter the millennium: Reflections and strategic intentions. Information Services in Schools (ISIS'99) Online Conference. Centre for Studies in Teacher Librarianship, Charles Sturt University, Wagga Wagga, NSW, 19-29 July.

Henri, J. \& Bonanno, K (1999). The information literate school community: Best practice. Wagga Wagga: CIS.

Henri, J. \& Hay, L. (1997). Understanding principal patronage: developing and piloting a quantitative instrument. Paper presented at the 63rd IFLA General Conference Conference Program and Proceedings - August 31- September 5. (Online) http://www.ifla.org/IV/ifla63/63heha.htm

Hopkins, D. (1985). A teacher's guide to classroom research. Philadelphia: Open University Press.

Hopkins, D., Ainscow, M. \& West, M. (1994). School improvement in an era of change. London: Cassell.

Kemmis, S. \& McTaggart, R. (1990). The action research planner. Geelong, Vic: Deakin University Press.

Kuhlthau's model of the stages of the information process (1993) from Kuhlthau, C. Seeking Meaning: A Process Approach to Library and Information Services. Norwood, N.J.: Ablex Publishing Corp., pp.45-51 (Online)

http:/www.library.arizona.edu/library/teams/indolit/nfoLit2000/Kuhlthaul.html

MacIsaac, D. (1996). An introduction to action research. (Online)

http://www.phy.nau.edu/ danmac/actionrsch.html

McKenzie, J. (1998). The information literate school. (Online)

http://www.fno.org/sept98/infolit.html

McKenzie, J. (2000). The ties that bind and the links that set us free. AASL President's Program ALA National conference Chicago July 8th. (Online) http://www.ala.org/events/ac2000/saturday.html http://newlibrary.org/aasl.html

Mitstifer, D. I. \& Miller, J. R. (1999). Strategic leadership of the professions: Agenda for change. East Lansing, MI: Kappa Omicron Nu Leadership Academy.

Nichols, J. (1999). Creating an information literate school: Information literacy in action. NASSP Bulletin 83(605): 75-81

Oberg, D. Hay, L. and Henri, J. (2000). The role of the principal in an information literate school community: Cross-country comparisons from an international research project. School Library Media Research 3. (Online) http://www.ala.org/aasl/SLMR/vol3! 
Oberg, D. Hay, L. \& Henri, J. (1998). Research on the principal's role in developing information literacy: An international study. IASL Newsletter March. (Online) http://www.iasl-slo.org/principals.html

Oosthuizen, M. (2000). Action research. In Research methods for students and professionals: Information management and systems ed. K. Williamson. Wagga Wagga, NSW: CIS

Pennell, V. (1999). Advocating information literacy. In Henri, J. \& Bonanno K. The information literate school community: Best practice. Wagga Wagga: CIS, 189-204

Perry, C. (2000) 'Mentoring and partnerships in collaboration: One school's story of professional development', Mentoring \& Tutoring, 8(3) 241-50.

Senge, P. M. (1990). The fifth discipline: The art and practice of the learning organization. New York: Currency Doubleday.

Senge, P. M. Kleiner, A. Roberts, C. Ross, R. B. \& Smith, B. J. (1994). The fifth discipline field book: Strategies and tools for building a learning organization. New York: Currency Doubleday.

Todd, R. (2001). Building a knowledge-sharing culture in schools: Knowledge management in action. In Hay, L. Hanson, K. \& Henri, J. New millennium, new horizons: information services in schools. Wagga Wagga, NSW: CSTL: 40-44.

Todd, R. (2001). Transitions for preferred futures of school libraries: Knowledge space, not information place; Connections, not collections; Actions, not positions; Evidence, not advocacy. Keynote presentation 2001 IASL Conference, Auckland New Zealand. 912 July. (Online) http://www.iaslslo.org/virtualpaper2001.html

The role of the principal in an information literate school community: findings from an international research project. (Online) http://athene.mit.csu.edu.au/ lhay/iasl/ilsc.html

Williamson, K. (2000) Research methods for students and professionals: Information management and systems. Wagga Wagga, NSW: CIS 


\section{Appendix 1}

\section{BENCHMARKS USED IN THE PROJECT}

$\checkmark$ The school has an information policy in place.

$\checkmark$ The school has adopted an information technology plan.

$\checkmark$ The school has a Homepage, an Intranet and Extranets. Learning is the dominant consideration in their design and maintenance.

$\checkmark$ The school has benchmarked information competencies that are expected of students at key points in their school career.

$\checkmark$ Students build a portfolio of evidence of their level of information literacy.

$\checkmark$ A significant percentage of school funds are budgeted for the provision of information services.

$\checkmark$ The school understands and defends the role of the teacher librarian, as articulated in policy documents.

$\checkmark$ The school requires that the teacher in charge of information services be a qualified teacher librarian.

$\checkmark$ The school supports the professional development of staff with respect to information literacy.

$\checkmark$ Students are able to recognise that their teachers are learning as well as teaching.

$\checkmark$ Information skills are taught/learned across the curriculum and in context.

$\checkmark$ The process of learning from information and of constructing knowledge is always paramount. Learning contexts are varied and involve students in the meaningful use of a wide range of information resources.

$\checkmark$ Teachers talk, dream, plan and teach as a team rather than as a group of individuals.

$\checkmark$ Reporting on student achievement focuses on how the student is maturing as a learner.

$\checkmark$ When assessing students, teachers are as interested in drafts and other working documents as they are in the final piece of work. (Teachers seek evidence that students are constructing their own meaning).

$\checkmark$ Teachers encourage student collaboration in many aspects of their learning. Information tasks are negotiated with the stakeholders-teacher librarian, class teachers, students, and special teachers.

$\checkmark$ The school monitors the information work demands that are placed on each student.

$\checkmark$ Special attention is given to 'out of school demands'. When students are required to undertake homework that involves a step(s) in the information process, teachers consider issues of social justice, equity, and the domestic demands placed on students.

$\checkmark$ Students are encouraged to provide constructive feedback to teachers with respect to information based learning tasks.

$\checkmark$ Students maintain logs or other records of their learning -the successes and challenges and are involved in self-assessment.

$\checkmark$ The school fosters knowledge management and expects the teacher librarian to provide timely information for corporate decision making, providing the resources to make this possible. (Henri 1999) 


\section{Appendix 2}

\section{TEACHER LIBRARIAN/CLASS TEACHER PARTNERSHIP RUBRIC}

\begin{tabular}{|c|c|c|c|c|}
\hline ACTIVITY & EXEMPLARY & GOOD & FAIR & LIMIITED \\
\hline ASSESSMENT & $\begin{array}{l}\text { Partners use various } \\
\text { assessment } \\
\text { strategies to } \\
\text { evaluate } \\
\text { students/services. } \\
\text { Assessment drives } \\
\text { curricular program. } \\
\text { Assessment IS used } \\
\text { to improve } \\
\text { resources/instruction } \\
\end{array}$ & $\begin{array}{l}\text { Partners regularly } \\
\text { assess } \\
\text { students/services. } \\
\text { Assessment informs } \\
\text { resources/instruction } \\
\text { decisions. }\end{array}$ & $\begin{array}{l}\text { TL or partner } \\
\text { sometimes assesses } \\
\text { students/services. } \\
\text { Assessment } \\
\text { sometimes impacts } \\
\text { curricular or } \\
\text { instructional } \\
\text { decisions. }\end{array}$ & $\begin{array}{l}\text { Partners do not } \\
\text { share assessments. } \\
\text { Assessments } \\
\text { seldom impact } \\
\text { curriculum } \\
\text { decisions. }\end{array}$ \\
\hline PLANNING & $\begin{array}{l}\text { TL is full } \\
\text { curriculum } \\
\text { development } \\
\text { partner. Full range } \\
\text { of info lit skills are } \\
\text { integrated in } \\
\text { curriculum. All } \\
\text { activities involving } \\
\text { the library are } \\
\text { planned } \\
\text { cooperatively. TL is } \\
\text { involved throughout } \\
\text { planning process. }\end{array}$ & $\begin{array}{l}\text { TL helps develop } \\
\text { curriculum. Most } \\
\text { info lit skills are } \\
\text { integrated into the } \\
\text { curriculum. Many } \\
\text { activities involving } \\
\text { the library are } \\
\text { planned } \\
\text { cooperatively. TL } \\
\text { plays significant role } \\
\text { in planning. }\end{array}$ & $\begin{array}{l}\text { TL supports } \\
\text { curriculum } \\
\text { development. } \\
\text { Some info lit skills } \\
\text { are integrated into } \\
\text { the curriculum. } \\
\text { Some activities } \\
\text { involving the } \\
\text { library are planned } \\
\text { cooperatively. TL } \\
\text { plays a limited role } \\
\text { in planning. }\end{array}$ & $\begin{array}{l}\text { TL follows } \\
\text { curriculum } \\
\text { development. A } \\
\text { few info lit skills } \\
\text { are integrated - or } \\
\text { are taught in } \\
\text { isolation. Few } \\
\text { activities involving } \\
\text { the library are } \\
\text { planned } \\
\text { cooperatively. TL } \\
\text { isn't part of plan. }\end{array}$ \\
\hline IMPLEMENTATION & $\begin{array}{l}\text { Partners usually } \\
\text { team-teach. } \\
\text { Partners use a } \\
\text { variety of strategies } \\
\text { and resources. } \\
\text { Partners assess } \\
\text { student achievement } \\
\text { regularly. Partners } \\
\text { modify plan as } \\
\text { needed in } \\
\text { collaboration with } \\
\text { others. } \\
\end{array}$ & $\begin{array}{l}\text { Partners sometimes } \\
\text { team-teach. Partners } \\
\text { share several } \\
\text { strategies and } \\
\text { resources. Partners } \\
\text { sometimes assess } \\
\text { student achievement. } \\
\text { Partners make some } \\
\text { plan changes as } \\
\text { needed. }\end{array}$ & $\begin{array}{l}\text { Partners decide } \\
\text { who teaches. } \\
\text { Partners share } \\
\text { some resources or } \\
\text { strategies. Partners } \\
\text { assess student } \\
\text { achievement } \\
\text { unevenly. Partners } \\
\text { occasionally } \\
\text { change plans. }\end{array}$ & $\begin{array}{l}\text { TL doesn't teach. } \\
\text { Resources and } \\
\text { strategies are not } \\
\text { shared. TL does } \\
\text { not access student } \\
\text { work. Partners } \\
\text { seldom change } \\
\text { plans. }\end{array}$ \\
\hline COMMITMENT & $\begin{array}{l}\text { Partners } \\
\text { communicate } \\
\text { regularly with each } \\
\text { other and with the } \\
\text { school community. } \\
\text { Partnership is long } \\
\text { term and close. } \\
\text { Peer coaching is } \\
\text { ubiquitous. }\end{array}$ & $\begin{array}{l}\text { Partners } \\
\text { communicate } \\
\text { regularly with each } \\
\text { other. Partners have } \\
\text { worked together and } \\
\text { coached each other } \\
\text { regularly. }\end{array}$ & $\begin{array}{l}\text { Partners sometimes } \\
\text { communicate and } \\
\text { work together, } \\
\text { usually for short- } \\
\text { term activities. } \\
\text { Peer coaching is } \\
\text { patchy. }\end{array}$ & $\begin{array}{l}\text { Partners seldom } \\
\text { communicate, } \\
\text { coach or work with } \\
\text { each other. } \\
\text { Activities are one } \\
\text { time only. }\end{array}$ \\
\hline
\end{tabular}

Adapted from Farmer, Lesley S. J. (1999) Partnerships for Lifelong Learning. Linworth. 